\title{
FLOOD MAGNITUDE AND FREQUENCY OF CHANDLERS RUN AT TWO SITES, AT PENNSAUKEN TOWNSHIP, NEW JERSEY
}

By Paul Dunne

\section{U.S. GEOLOGICAL SURVEY}

Open-File Report 94-500

Prepared in cooperation with the

NEW JERSEY DEPARTMENT OF TRANSPORTATION

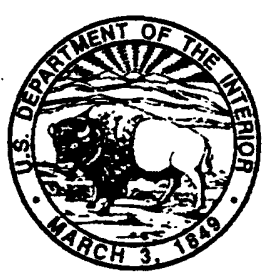

This report was prepared by the U.S Geological Survey in accordance with New Jersey Department of Transportation contract no. $93 \mathrm{PE} 06$ under the direction of Acting State Coordinator Robert J. Cunningham and Project Manager Kal Satija.

West Trenton, New Jersey 


\title{
U.S. DEPARTMENT OF THE INTERIOR \\ BRUCE BABBITT, Secretary
}

\author{
U.S. GEOLOGICAL SURVEY \\ Gordon P. Eaton, Director
}

For additional information write to:

District Chief

U.S Geological Survey

Mountain View Office Park

810 Bear Tavem Road, Suite 206

West Trenton, NJ 08628
Copies of this report can be purchased from:

U.S. Geological Survey

Earth Science Information Center

Open-File Reports Section

Box 25286, MS 517

Denver Federal Center

Denver, CO 80225 


\section{CONTENTS}

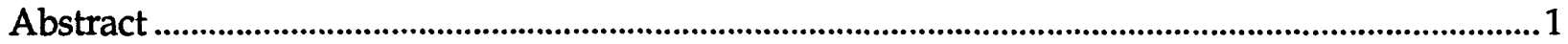

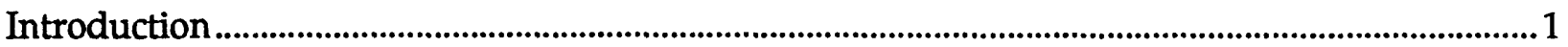

Methods used to estimate flood magnitude and frequency................................................................

Rational method...............................................................................................................................

Special Report 38 method (New Jersey Department of Environmental Protection) ............3

Index-flood method (U.S. Geological Survey)........................................................................... 4

Technical Release 55 graphical peak discharge method (U.S. Soil Conservation Service). 4

Special Projects Memo 480 method (U.S. Army Hydrologic Engineering Center)............... 4

Transfer method (U.S. Geological Survey) ..................................................................................

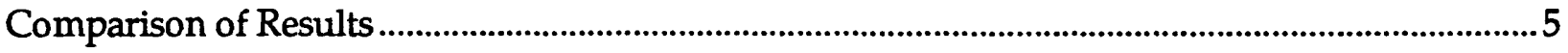

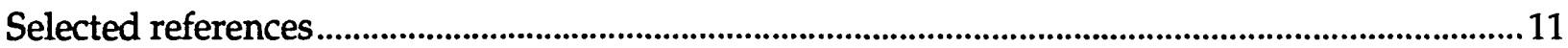

\section{ILLUSTRATIONS}

Figure 1.-Map showing location of Chandlers Run at the culverts on New Jersey Routes 612 and 70 (sites A and B, respectively), at Pennsauken Township, New Jersey........... 2

\section{TABLES}

Table 1.-Explanatory variables for the flood-magnitude and -frequency methods, Chandlers Run, at the culvert on New Jersey Route 612 (site A), Pennsauken Township, New Jersey.

2.-Explanatory variables for the flood-magnitude and -frequency methods, Chandlers Run, at the culvert on New Jersey Route 70 (site B), Pennsauken Township, New Jersey

3.-Estimates of flood magnitude for selected flood frequencies, Chandlers Run, at the culvert on New Jersey Route 612 (site A), Pennsauken Township, New Jersey ...... 9

4.-Estimates of flood magnitude for selected flood frequencies, Chandlers Run, at the culvert on New Jersey Route 70 (site B), Pennsauken Township, New Jersey....... 10 


\section{CONVERSION FACTORS}

\section{Multiply}

foot (ft)

mile (mi)

square mile $\left(\mathrm{mi}^{2}\right)$

foot per mile $(\mathrm{ft} / \mathrm{mi})$

inch per hour (in/hr)

cubic foot per second $\left(\mathrm{ft}^{3} / \mathrm{s}\right)$
By

0.3048

1.609

2.590

0.189

25.4

0.028
To obtain

meter

kilometer

square kilometer

meter per kilometer

millimeter per hour

cubic meter per second 


\title{
FLOOD MAGNITUDE AND FREQUENCY OF CHANDLERS RUN AT TWO SITES, AT PENNSAUKEN TOWNSHIP, NEW JERSEY
}

\author{
By Paul Dunne
}

\begin{abstract}
Six methods were used to estimate the magnitude and frequency of floods at Chandlers Run at the culvert on New Jersey Route 612 and at a second site about 2,100 feet upstream, at New Jersey Route 70, at Pennsauken Township, New Jersey. Flood magnitude and frequency calculated by the six methods, as well as drainage-basin characteristics, are included in this report. The 100-year-flood estimates for the culvert site on New Jersey Route 612 range from 268 cubic feet per second to 2,050 cubic feet per second. The 100-year-flood estimates for the upstream site at New Jersey Route 70 range from 246 cubic feet per second to 2,320 cubic feet per second. Flood magnitude and frequency estimates obtained by using the New Jersey Department of Environmental Protection Special Report 38 method and other previously published estimates fall within the range of values estimated by using the U.S. Geological Survey transfer method with data collected from three nearby crest-stage gages.
\end{abstract}

\section{INTRODUCTION}

Information on the magnitude and frequency of floods is critical to the planning and design of highway culverts and bridges. Such information is not available for many stream crossings in New Jersey. To fulfill this information need, the U.S. Geological Survey (USGS), in cooperation with the New Jersey Department of Transportation, began an analysis of flood data from stream-crossing sites on New Jersey streams. This report presents results of the analysis for Chandlers Run at the culvert on N.J. Route 612, at Pennsauken Township, N.J., (site A) and at a second site (site B) about 2,100 ft upstream from site A at N.J. Route 70 (fig. 1). The drainage area upstream from site $A$ is $1.03 \mathrm{mi}^{2}$. The drainage area upstream from site $B$ is 0.92 $\mathrm{mi}^{2}$. A field reconnaissance was performed on June 9,1993 , to verify the locations of the drainage divides and land use. Because the direction of storm-sewer drainage in some parts of the basin is uncertain, the calculated drainage area is approximate.

The flooding problem in this area has been depicted in newspaper articles. According to a report in a local newspaper (Courier-Post Newspaper, 1989) 4.38 inches of rain fell during 6 hours, causing flooded homes, traffic problems, collapsed dams, and electric- power outages. A few bridges and roads were damaged or washed out near the study sites. The recurrence interval and discharge of this flood are undetermined.

The flood-insurance study for Pennsauken Township (Federal Emergency Management Agency, October 1976) did not include a detailed study of this part of Chandler Run; therefore, flood discharges were not determined previously. 

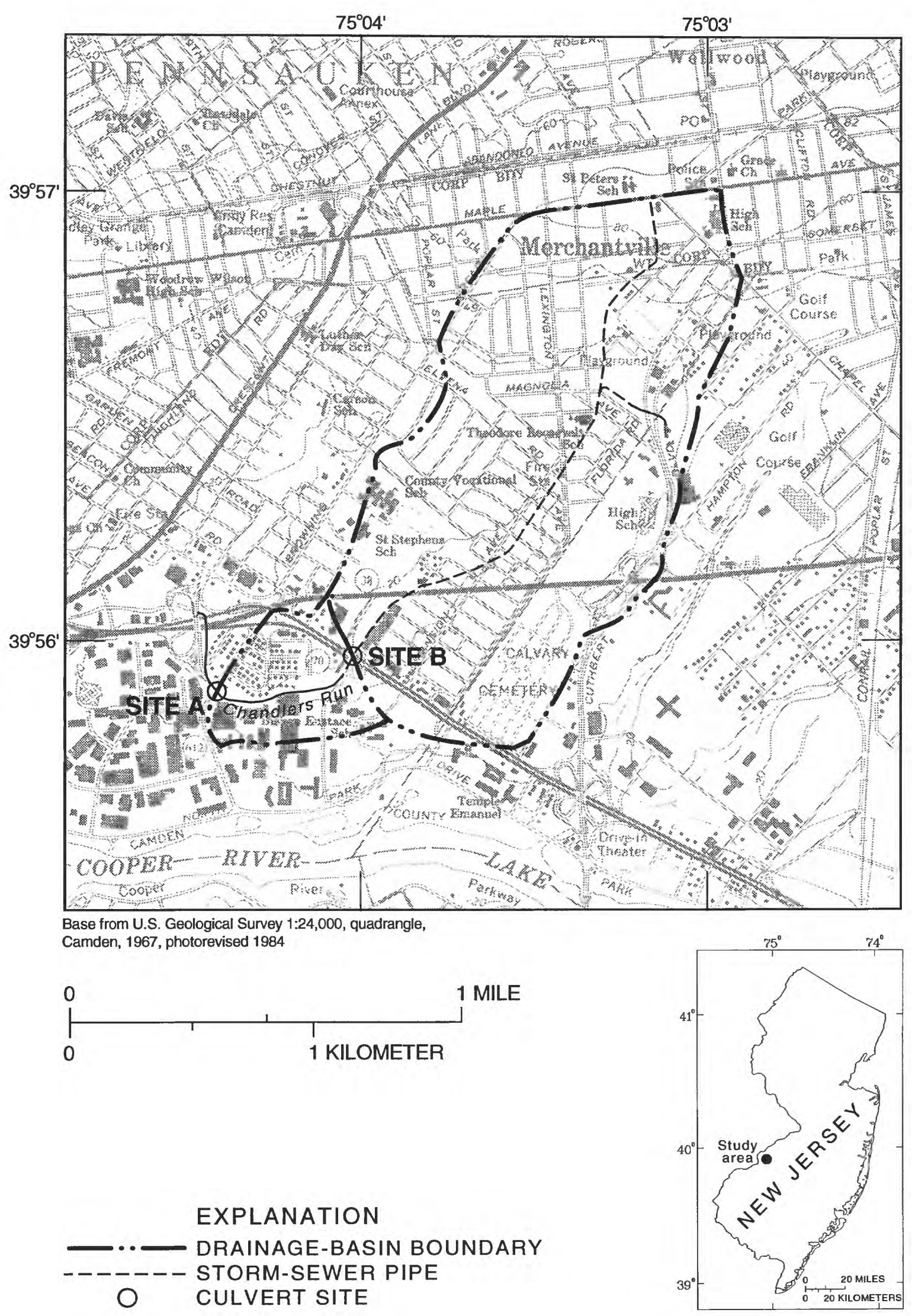

Figure 1. Location of Chandlers Run at the culverts on New Jersey Routes 612 and 70 (sites A and B, respectively), at Pennsuaken Township, New Jersey 


\section{METHODS USED TO ESTIMATE FLOOD MAGNITUDE AND FREQUENCY}

Various flood magnitude and frequency methods were used to determine the flood magnitudes that are likely to be exceeded at this site within a given number of years (recurrence interval). The methods used include the rational method (Chow and others, 1988), New Jersey Department of Environmental Protection (NJDEP) Special Report 38 method (Stankowski, 1974), U.S. Geological Survey (USGS) index-flood method (Thomas, 1964), USGS transfer method (N.J. Department of Environmental Protection, 1988), U.S. Soil Conservation Service (SCS) Technical Release 55 (TR-55) method (U.S. Soil Conservation Service, 1986), and the U.S. Army Hydrologic Engineering Center (HEC) Special Projects Memo 480 method (U.S. Army Corps of Engineers, 1977).

Data and computations used in this study can be obtained from the U.S. Geological Survey, 810 Bear Tavern Road, Suite 206, West Trenton, NJ 08628.

\section{Rational Method}

The rational method is based on the concept that if a rainfall of a particular intensity begins instantaneously and continues indefinitely across a watershed, the runoff rate will increase until the time of concentration is reached, which is the time when the entire watershed is contributing to the flow at the outlet (Chow and others, 1988). The time of concentration (the time needed for water to travel from the farthest point in the watershed to the outlet) is computed by summing the travel times for consecutive components of a drainage system (U.S. Soil Conservation Service, 1986). Many factors, including channel shape, surface roughness, and slope, affect the time of concentration.

The equation that expresses this method is:

$$
Q=C i A,
$$

where $Q$ is the rate of peak discharge at the time of concentration, in cubic feet per second; $i$ is the rainfall intensity, in inches per hour; $A$ is the watershed area, in acres; and $C$ is the runoff coefficient. The runoff coefficient depends on various watershed characteristics, including the composition and condition of the soil, the type and condition of land use, and the percent imperviousness of the watershed. Appropriate runoff-coefficient values based on these watershed characteristics were chosen from a table (N.J. Department of Environmental Protection and Energy, 1993). This method is recommended for the calculation of peak discharges in homogeneous drainage areas up to $0.5 \mathrm{mi}^{2}$ in size (N.J. Department of Environmental Protection and Energy, 1993).

\section{Special Report 38 Method (New Jersey Department of Environmental Protection)}

This method consists of the development and use of a set of regression equations for the 2-, 5-, 10-, 25-, 50-, and 100-year floods based on the watershed characteristics drainage area, basin storage (percent area of lakes and swamps, plus 1.0 percent in order to avoid zero values), and impervious cover (based on population density). This method is recommended for use in drainage areas of 1 to $1,000 \mathrm{mi}^{2}$ (Stankowski, 1974). 


\section{Index-Flood Method (U.S. Geological Survey)}

Flood estimates are made with this method by using two graphical curves. One curve expresses the relation between the mean annual flood and the size of the drainage basin; the other expresses the ratio between the mean annual flood and floods of other recurrence intervals. The mean annual flood is adjusted on the basis of the percentage of lakes and swamps in the drainage basin. This method is recommended for drainage areas greater than 4 $\mathrm{mi}^{2}$ and is most accurate for drainage areas of 10 to $200 \mathrm{mi}^{2}$ (Thomas, 1964).

\section{Technical Release 55 Graphical Peak Discharge Method (U.S. Soil Conservation Service)}

For this method, a SCS curve number, which represents the overall soil type, land use, and antecedent soil-moisture conditions, is determined for the basin. This curve number is used to account for the initial abstraction and infiltration losses. Other required input parameters are the 24-hour rainfall associated with the desired frequency, the drainage-basin area, and the time of concentration (total travel time). The time of concentration for a basin is determined by using a set of equations describing the travel time for the overland- flow or sheet-flow segment, the shallow-concentrated-flow segment, and the open-channel-flow segment. The time of concentration is the sum of the ratios of flow length to flow velocity for each segment. This value depends on the surface type, hydraulic radius, cross-sectional-flow area, wetted perimeter, land slope, channel slope, and Manning's roughness coefficient. This method is recommended for drainage areas of less than $5 \mathrm{mi}^{2}$ (U.S. Soil Conservation Service, 1986).

\section{Special Projects Memo 480 Method (U.S. Army Hydrologic Engineering Center)}

This method is based on multiple-regression equations for the mean, standard deviation, and skewness of the logarithms of the annual peak flows at 58 long-record streamflow-gaging stations; the equations are based on three watershed characteristics (drainage area, main channel slope, and forest cover). An adjustment is made by estimating a generalized skew coefficient based on the log-Pearson Type III distribution (Interagency Advisory Committee on Water Data, 1982). This method is recommended for use for drainage areas of 10 to $300 \mathrm{mi}^{2}$ (Interagency Advisory Committee on Water Data, 1982).

\section{Iransfer Method (U.S. Geological Survey)}

The relation that is used to calculate flood estimates is based on a ratio of drainage areas raised to an exponent:

$$
\frac{Q_{P I}}{Q_{P G}}=\left(\frac{A_{P I}}{A_{P G}}\right)^{0.75}
$$

where $Q_{P I}$ is the design flood at the point of interest, $Q_{P G}$ is the design flood at the gaged point, $A_{P I}$ is the drainage area at the point of interest, and $A_{P G}$ is the drainage area at the gaged 
point. An exponent of 0.75 is used; the exponent is based on studies of 10-year recurrence interval floods in New Jersey (New Jersey Department of Environmental Protection and Energy, 1993). This method is recommended for drainage areas that are either less than twice or more than half the drainage area of the gaged point (New Jersey Department of Environmental Protection and Energy, 1993).

\section{COMPARISON OF RESULTS}

The explanatory variables used in applying the methods described above at site $\mathrm{A}$ and site $B$ are listed in tables 1 and 2, respectively. The flood-magnitude and -frequency estimates for both sites obtained by using each of the various methods are shown in tables 3 and 4, respectively. The range in the estimates is large; estimates of the 100-year-flood discharge at site A range from 268 to $2,050 \mathrm{ft}^{3} / \mathrm{s}$, and the estimates of the 100-year-flood discharge at site $B$ range from 246 to $2,320 \mathrm{ft}^{3} / \mathrm{s}$.

Flood data from nearby streamflow-gaging or crest-stage gaging stations provide a good indication of the flood magnitude and frequency that can be expected at an ungaged site, particularly if drainage area and other basin characteristics are similar and the record length is sufficiently large. The estimates developed by using the various methods are compared with discharge data that have been transferred to the culvert sites by using the USGS transfer method.

In New Jersey, for streams that drain areas between 1 and $5 \mathrm{mi}^{2}$, the NJDEP Special Report 38 method and the TR-55 method (New Jersey Department of Environmental Protection and Energy, 1993) are the most frequently used. The drainage area of site A falls within these limits. The discharge values estimated by using the TR- 55 method, as well as the rational method and the HEC Special Project Memo 480 method, are much greater than the values estimated by using the USGS transfer method with data collected from three nearby crest-stage gages (stations 01467057, 01467305, and 01467317; Bauersfeld and others, 1993). The estimates obtained by using the NJDEP Special Report 38 method fall within the range of peak discharges estimated by using the USGS transfer method.

For streams draining areas between 0.5 and $1 \mathrm{mi}^{2}$, the TR-55 method (New Jersey Department of Environmental Protection and Energy, 1993) is the most frequently used. The drainage area of site B falls within this limit. The estimates obtained by using the TR-55 method were from 3 to 7 times the values estimated by using the USGS transfer method with data collected from the three nearby crest-stage gages. Newton and Herrin (1982) summarized a U.S. Water Resources Council report on estimating flood magnitude and frequency for ungaged sites by using various methods and concluded that the TR- 55 method tends to overestimate flood magnitudes. The drainage area of site $B$ falls just outside the recommended range for using the NJDEP Special Report 38 method; however, estimates obtained by using the NJDEP Special Report 38 method fall within the range of values estimated by using the USGS transfer method with data collected from the three nearby crest-stage gages.

Drainage areas of both sites are outside the recommended ranges for using the USGS index-flood method (Thomas, 1964) and the HEC Special Project Memo 480 method (U.S. Army Corps of Engineers, 1977). The rational method is not recommended by the New Jersey Department of Environmental Protection and Energy (1993) for sites with these drainage areas. The use of the NJDEP Special Report 38 method seems to be appropriate for both sites. 
Table 1. Explanatory variables for the flood-magnitude and -frequency methods, Chandlers Run, at the culvert on New Jersey Route 612 (site A), Pennsauken Township, New Jersey

Drainage area: 1.03 square miles

Latitude: $39^{\circ} 55^{\prime} 55^{\prime \prime}$

Longitude: $74^{\circ} 04^{\prime} 24^{\prime \prime}$

Highway: New Jersey Route 612

U.S.Geological Survey 7-1/2-minute Quadrangle: Camden

\begin{tabular}{|c|c|c|}
\hline Variable & Value & Unit \\
\hline Drainage area & $=1.03$ & square miles \\
\hline Main channel slope & $=35.5$ & feet per mile \\
\hline Total stream length & $=2.0$ & miles \\
\hline Surface storage index & $=1.0$ & percent \\
\hline Population density (1990) & $=3,622$ & persons per square mile \\
\hline Impervious cover & $=24.7$ & percent \\
\hline Forest cover & $=3.0$ & percent \\
\hline Regional skew coefficient ${ }^{1}$ & $=0.3$ & \\
\hline Lake and swamp area & $=0.0$ & percent \\
\hline Hydrologic area $^{2}$ & $=3$ & \\
\hline Flood-frequency region ${ }^{2}$ & $=\mathrm{C}$ & \\
\hline Rational method runoff coefficient ${ }^{3}$ & $=0.65$ & \\
\hline Runoff curve number ${ }^{4}$ & $=88$ & \\
\hline Time of concentration ${ }^{4}$ & $=1.09$ & hours \\
\hline 2-year, 24-hour rainfall ${ }^{5}$ & $=3.30$ & inches \\
\hline 5-year, 24-hour rainfall & $=4.40$ & inches \\
\hline 10-year, 24-hour rainfall & $=5.20$ & inches \\
\hline 25-year, 24-hour rainfall & $=5.90$ & inches \\
\hline 50-year, 24-hour rainfall & $=6.60$ & inches \\
\hline 100-year, 24-hour rainfall & $=7.30$ & inches \\
\hline 2-year rainfall intensity ${ }^{6}$ & $=1.43$ & inches per hour \\
\hline 5-year rainfall intensity & $=1.89$ & inches per hour \\
\hline 10-year rainfall intensity & $=2.20$ & inches per hour \\
\hline 25-year rainfall intensity & $=2.52$ & inches per hour \\
\hline 50-year rainfall intensity & $=2.84$ & inches per hour \\
\hline 100 -year rainfall intensity & $=3.13$ & inches per hour \\
\hline
\end{tabular}

${ }^{1}$ From U.S. Army Corps of Engineers, 1977

${ }^{2}$ From Thomas, 1964

${ }^{3}$ From New Jersey Department of Environmental Protection and Energy, 1993

${ }^{4}$ From U.S. Soil Conservation Service, 1986

${ }^{5}$ All rainfall values from Hershfield, 1961

${ }^{6}$ All rainfall intensity values from Frederick and others, 1977 
Table 2. Explanatory variables for the flood-magnitude and -frequency methods, Chandlers Run, at the culvert on New Jersey Route 70 (Site B), Pennsauken Township, New Jersey

Drainage area: 0.92 square miles

Latitude: $39^{\circ} 55^{\prime} 59^{\prime \prime}$

Longitude: $74^{\circ} 04^{\prime} 01^{\prime \prime}$

Highway: New Jersey Route 70

U.S.Geological Survey 7-1/2-minute Quadrangle: Camden

\begin{tabular}{|c|c|c|}
\hline Variable & Value & Unit \\
\hline Drainage area & $=0.92$ & square miles \\
\hline Main channel slope & $=52.5$ & feet per mile \\
\hline Total stream length & $=1.6$ & miles \\
\hline Surface storage index & $=1.0$ & percent \\
\hline Population density (1990) & $=3,661$ & persons per square mile \\
\hline Impervious cover & $=24.8$ & percent \\
\hline Forest cover & $=3.0$ & percent \\
\hline Regional skew coefficient ${ }^{1}$ & $=0.3$ & \\
\hline Lake and swamp area & $=0.0$ & percent \\
\hline Hydrologic area ${ }^{2}$ & $=3$ & \\
\hline Flood-frequency region ${ }^{2}$ & $=\mathrm{C}$ & \\
\hline Rational method runoff coefficient ${ }^{3}$ & $=0.64$ & \\
\hline Runoff curve number ${ }^{4}$ & $=88$ & \\
\hline Time of concentration ${ }^{4}$ & $=0.81$ & hours \\
\hline 2-year, 24 -hour rainfall ${ }^{5}$ & $=3.30$ & inches \\
\hline 5-year, 24-hour rainfall & $=4.40$ & inches \\
\hline 10-year, 24-hour rainfall & $=5.20$ & inches \\
\hline 25-year, 24-hour rainfall & $=5.90$ & inches \\
\hline 50-year, 24-hour rainfall & $=6.60$ & inches \\
\hline 100-year, 24-hour rainfal & $=7.30$ & inches \\
\hline 2 -year rainfall intensity ${ }^{6}$ & $=1.67$ & inches per hour \\
\hline 5-year rainfall intensity & $=2.09$ & inches per hour \\
\hline 10-year rainfall intensity & $=2.40$ & inches per hour \\
\hline 25-year rainfall intensity & $=2.83$ & inches per hour \\
\hline 50-year rainfall intensity & $=3.16$ & inches per hour \\
\hline 100 -year rainfall intensity & $=3.50$ & inches per hour \\
\hline
\end{tabular}

${ }^{1}$ From U.S. Army Corps of Engineers, 1977

${ }^{2}$ From Thomas, 1964

${ }^{3}$ From New Jersey Department of Environmental Protection and Energy, 1993

${ }^{4}$ From U.S. Soil Conservation Service, 1986

${ }^{5}$ All rainfall values from Hershfield, 1961

${ }^{6}$ All rainfall intensity values from Frederick and others, 1977 
The consulting firm Urban Engineers, Inc., completed a study of Chandlers Run in 1992 for the New Jersey Department of Transportation (Urban Engineers, Inc., 1992). Floodfrequency estimates made for the two sites are included in tables 3 and 4 . These estimates were made by using the TR- 55 method with some site-specific modifications in the computations. The modifications were made to account for some of the hydraulic peculiarities in this basin. The estimates made by Urban Engineers, Inc., fall within the range of values estimated by using the USGS transfer method with data collected from the three nearby crest-stage gages. 
Table 3. Estimates of flood-magnitude for selected flood frequencies, Chandlers Run, at the culvert on New Jersey Route 612 (site A), Pennsauken Township, New Jersey

[Q, flood-magnitude estimates in cubic feet per second along with number, indicating the frequency of the recurrance interval in years; DA, drainage area, in square miles; S, main-channel slope, in feet per mile; St, surface storage index, in percent; I, index of manmade impervious cover, in percent of drainage area; YR, years of record; $D$, distance from station used in USGS transfer method from flood site; NJDEP, New Jersey Department of Environmental Protection; NJDEPE, New Jersey Department of Environmental Protection and Energy; USGS, U.S. Geological Survey; SCS, Soil Conservation Service; HEC, Hydrologic Engineering Center; SPM, Special Projects Memo; TR, Technical Release; SR, Special Report;

- , not applicable]

Drainage area: 1.03 square miles

Latitude: $39^{\circ} 55^{\prime} 55^{\prime \prime}$

Longitude: $74^{\circ} 04^{\prime} 24^{\prime \prime}$

Highway: New Jersey Route 612

U.S.Geological Survey 7-1/2-minute Quadrangle: Camden

\begin{tabular}{lrrrrrrrrrrrr}
\hline \multicolumn{1}{c}{ Estimating method } & Q2 & Q5 & Q10 & Q25 & Q50 & Q100 & DA & S & St & I & Yr & D \\
\hline \hline Rational method & 612 & 809 & 942 & 1,080 & 1,220 & 1,340 & - & - & - & - & - & - \\
NJDEP SR 38 & 143 & 209 & 276 & 375 & 451 & 553 & 1.03 & 35.5 & 1.0 & 24.7 & - & - \\
USGS index method & 75 & 124 & 160 & 210 & 254 & 305 & - & - & - & - & - & - \\
SCS TR-55 & 611 & 908 & 1,130 & 1,330 & 1,520 & 1,720 & - & - & - & - & - & - \\
HEC SPM 480 & 298 & 571 & 819 & 1,220 & 1,600 & 2,050 & - & - & - & - & - & - \\
USGS transfer method & & & & & & & & & & & & \\
Station 01467057 & 154 & 241 & 307 & 403 & 483 & 568 & 5.77 & 12.3 & 1.0 & 15.2 & 14 & 7.8 \\
$\quad$ Station 01467305 & 144 & 175 & 197 & 224 & 246 & 268 & 1.33 & 48.8 & 1.4 & 33.0 & 26 & 2.2 \\
$\quad$ Station 01467317 & 65 & 134 & 203 & 326 & 451 & 607 & .63 & 57.5 & 1.0 & 38.0 & 27 & 3.8 \\
Urban Engineers, Inc., & - & - & - & - & - & 477 & .949 & - & - & - & - & - \\
report & & & & & & & & & & & & \\
\hline
\end{tabular}

1 This method recommended by Stankowski (1974) for a drainage basin of this size

2 This method recommended by NJDEPE (1993) for a drainage basin of this size 
Table 4. Estimates of flood-magnitude for selected flood frequencies, Chandlers Run, at the culvert on New Jersey Route 70 (site B), Pennsauken Township, New Jersey

[Q, flood-magnitude estimates in cubic feet per second along with number, indicating the frequency of the recurrance interval in years; DA, drainage area, in square miles; $\mathrm{S}$, main-channel slope, in feet per mile; $\mathrm{St}$, surface storage index, in percent; $I$, index of manmade impervious cover, in percent of drainage area; $Y R$, years of record; D, distance from station used in USGS transfer method from flood site; NJDEP, New Jersey Department of Environmental Protection; NJDEPE, New Jersey Department of Environmental Protection and Energy; USGS, U.S. Geological Survey; SCS, Soil Conservation Service; HEC, Hydrologic Engineering Center; SPM, Special Projects Memo; TR, Technical Release; SR, Special Report; --, not applicable]

Drainage area: 0.92 square miles

Latitude: $39^{\circ} 55^{\prime} 59^{\prime \prime}$

Longitude: $74^{\circ} 04^{\prime} 01^{\prime \prime}$

Highway: New Jersey Route 70

U.S.Geological Survey 7-1/2-minute Quadrangle: Camden

\begin{tabular}{lrrrrrrrrrrrr}
\hline \multicolumn{1}{c}{ Estimating method } & Q2 & Q5 & Q10 & Q25 & Q50 & Q100 & DA & S & St & I & Yr & D \\
\hline \hline Rational method & 629 & 787 & 904 & 1,070 & 1,190 & 1,320 & - & - & - & - & - & - \\
NJDEPE SR 38 & 143 & 209 & 278 & 378 & 454 & 557 & .92 & 52.2 & 1.0 & 24.8 & - & - \\
USGS index method & 69 & 113 & 146 & 192 & 232 & 279 & - & - & - & - & - & - \\
SCS TR-55 & 635 & 943 & 1,170 & 1,380 & 1,580 & 1,790 & - & - & - & - & - & - \\
HEC SPM 480 & 333 & 641 & 921 & 1,380 & 1,810 & 2,320 & - & - & - & - & - & - \\
USGS transfer method & & & & & & & & & & & & \\
$\quad$ Station 01467057 & 142 & 221 & 282 & 370 & 444 & 522 & 5.77 & 12.3 & 1.0 & 15.2 & 14 & 7.8 \\
$\quad$ Station 01467305 & 132 & 161 & 181 & 206 & 226 & 246 & 1.33 & 48.8 & 1.4 & 33.0 & 26 & 2.2 \\
$\quad$ Station 01467317 & 59 & 123 & 187 & 300 & 414 & 557 & .63 & 57.5 & 1.0 & 38.0 & 27 & 3.8 \\
Urban Engineers, Inc., & - & - & - & - & - & 440 & .875 & - & - & - & - & - \\
report & & & & & &. & & & & & & \\
\hline
\end{tabular}

${ }^{1}$ This method recommended by Stankowski (1974) for a drainage basin of this size

2 This method recommended by NJDEPE (1993) for a drainage basin of this size 


\section{SELECTED REFERENCES}

Bauersfeld, W.R., Moshinsky, E.W., and Gurney, C.E., 1993, Water resources data, New Jersey, water year 1992, Volume 1. Surface-water data: U.S. Geological Survey Water Data Report NJ-92-1, $507 \mathrm{p}$.

Chow, V.T., Maidment, D.R., and Mays, L.W., 1988, Applied hydrology: New York, McGrawHill Book Co., 572 p.

Courier-Post Newspaper, 1989, Storm of century hits area: Cherry Hill, N.J., Courier-Post Newspaper, October 21, 1989.

Federal Emergency Management Agency, 1976, Flood insurance study of Pennsauken Township, New Jersey: Federal Emergency Management Agency, October 1976, 19 p.

Frederick, R.H., Myers, V.A., and Auciello, E.P., 1977, Five- to 60- minute precipitation frequency for the eastern and central United States: National Oceanic and Atmospheric Administration Technical Memorandum NWS HYDRO-35, Silver Spring, Md., June 1977, $36 \mathrm{p}$.

Hershfield, D.M., 1961, Rainfall frequency atlas of the United States for durations from 30 minutes to 24 hours and return periods from 1 to 100 years: U.S. Weather Bureau Technical Paper No. 40, Washington, D.C., 115 p.

Interagency Advisory Committee on Water Data, 1982, Guidelines for determining flood flow frequency: Bulletin 17B of the Hydrology Subcommittee, Office of Water Data Coordination, U.S. Geological Survey, Reston, Va., 183 p.

New Jersey Department of Environmental Protection and Energy, 1993, Technical manual for stream encroachment permits: New Jersey Department of Environmental Protection and Energy, 100 p., 6 app.

Newton, D.W., and Herrin, J.C., 1982, Assessment of commonly used methods of estimating flood frequency: Transportation Research Record 896, Transportation Research Board, Washington, D.C., p. 10-30.

Stankowski, S.J., 1974, Magnitude and frequency of floods in New Jersey with effects of urbanization: New Jersey Department of Environmental Protection, Special Report 38, 46 p.

Thomas, D.M., 1964, Floods in New Jersey, magnitude and frequency: New Jersey Department of Conservation and Economic Development, Water Resources Circular 13, 145 p.

Tice, R.H., 1968, Magnitude and frequency of floods in the United States. Part 1-B. North Atlantic slope basins, New York to York River: U.S. Geological Survey Water-Supply Paper 1672, $585 \mathrm{p}$.

Urban Engineers, Inc., 1992, Chandlers Run (vicinity of Route 70) drainage outfall, Pennsauken Township, Camden County, New Jersey: Pennsauken, N.J., Urban Engineers, Inc., 22 p. 


\section{SELECTED REFERENCES--Continued}

U.S. Army Corps of Engineers, 1977, Generalized skew study for the State of New Jersey: U.S. Army Corps of Engineers, Hydrologic Engineering Center, Special Projects Memo 480, 43 p., 3 app.

U.S. Soil Conservation Service, 1966, Soil survey, Camden County, New Jersey: Washington, D.C., U.S. Soil Conservation Service, 94 p.

U.S. Soil Conservation Service, 1986, Urban hydrology for small watersheds: Engineering Division Technical Release 55, Washington, D.C., 162 p. 